\title{
Translation and validation of the Korean version of the clinical frailty scale in older patients
}

Ryoung-Eun $\mathrm{Ko}^{1 \dagger}$, Seong Mi Moon ${ }^{2 \dagger}$, Danbee Kang ${ }^{3,4}$, Juhee Cho ${ }^{3,4,5}$, Chi Ryang Chung ${ }^{1}$, Yunhwan Lee ${ }^{6,7}$, Yun Soo Hong ${ }^{8}$, So Hee Lee ${ }^{9}$, Jung Hee Lee ${ }^{10}$ and Gee Young Suh ${ }^{1,11^{*}}$ (D)

\begin{abstract}
Background: Frailty is a multidimensional syndrome that leads to an increase in vulnerability. Previous studies have suggested that frailty is associated with poor health-related outcomes. For frailty screening, the Clinical Frailty Scale (CFS) is a simple tool that is widely used in various translated versions. We aimed to translate the CSF into Korean and evaluated its contents and concurrent validity.

Methods: Translations and back-translations of the CFS were conducted independently. A multidisciplinary team decided the final CFS-K. Between August 2019 and April 2020, a total of 100 outpatient and inpatient participants aged $\geq 65$ years were enrolled prospectively. The clinical characteristics were evaluated using the CFS-K. The CFS-K scores were compared with those of other frailty screening tools using Pearson's correlation coefficient and Spearman's rank correlation. The area under curve (AUC) for identifying the Eastern Cooperative Oncology Group Performance Status (ECOG PS) grade 3 or more was calculated for the CFS-K and other screening tools.

Results: The mean age of the participants was 76.5 years (standard deviation [SD], 7.0), and 63 (63\%) participants were male. The mean CFS-K was $4.8(\mathrm{SD}, 2.5)$. Low body mass index $(p=0.013)$ and low score on the Korean version of the Mini-Mental State Examination $(p<0.001)$ were significantly associated with high CFS-K scores, except for those assigned to scale 9 (terminally ill). The CFS-K showed a significant correlation with other frailty screening tools ( $R=0.7742-0.9190 ; p<0.01$ ), except in the case of those assigned to scale 9 (terminally ill). In comparison with other scales, the CFS-K identified ECOG PS grade 3 or more with the best performance $(A \cup C=$ 0.99). Patients assigned to scale 9 on the CFS-K (terminally ill) had similar frailty scores to those assigned to scale 4 (vulnerable) or 5 (mildly frail).
\end{abstract}

(Continued on next page)

\footnotetext{
* Correspondence: suhgy@skku.edu

${ }^{+}$Ryoung-Eun Ko and Seong Mi Moon contributed equally to this work.

'Department of Critical Care Medicine, Samsung Medical Center,

Sungkyunkwan University School of Medicine, 81 Irwon-ro, Gangnam-gu,

Seoul 06351, Republic of Korea

${ }^{11}$ Division of Pulmonary and Critical Care Medicine, Department of Medicine,

Samsung Medical Center, Sungkyunkwan University School of Medicine,

Seoul, Republic of Korea

Full list of author information is available at the end of the article
}

(c) The Author(s). 2021 Open Access This article is licensed under a Creative Commons Attribution 4.0 International License, which permits use, sharing, adaptation, distribution and reproduction in any medium or format, as long as you give appropriate credit to the original author(s) and the source, provide a link to the Creative Commons licence, and indicate if changes were made. The images or other third party material in this article are included in the article's Creative Commons licence, unless indicated otherwise in a credit line to the material. If material is not included in the article's Creative Commons licence and your intended use is not permitted by statutory regulation or exceeds the permitted use, you will need to obtain permission directly from the copyright holder. To view a copy of this licence, visit http://creativecommons.org/licenses/by/4.0/ The Creative Commons Public Domain Dedication waiver (http://creativecommons.org/publicdomain/zero/1.0/) applies to the data made available in this article, unless otherwise stated in a credit line to the data. 
(Continued from previous page)

Conclusions: In conclusion, the CFS-K is a valid scale for measuring frailty in older Korean patients. The CFS-K scores were significantly correlated with the scores of other scales. To evaluate the predictive and prognostic value of this scale, further larger-scale studies in various clinical settings are warranted.

Keywords: Clinical frailty scale, Frailty, Translation, Validation, Korean

\section{Background}

Frailty is a multidimensional syndrome involving loss of reserves (energy, physical ability, cognition, and health) accompanied by an increase in vulnerability to increased dependency and/or mortality when exposed to a stressor $[1,2]$. Frailty is either physical or psychological or a combination of both [2]. Physical frailty is characterized by diminished strength and endurance and reduced physiologic function [1] and associated with increased health-related outcomes in older populations, including hospitalization, nursing home admission, re-admission, and mortality [3-10]. Therefore, for physicians, frailty screening is useful for risk stratification, goal setting and advanced care planning, and frailty-targeted interventions [1, 11-13].

A recent consensus conference which was attended by the international societies and experts in the area of frailty recommended screening for frailty in all older persons and individuals with significant weight loss due to chronic disease [1]. They also suggested instruments for several screening tests such as the Fatigue, Resistance, Ambulation, Illness, and Loss of weight (FRAIL) questionnaire, Cardiovascular Health Study (CHS) frailty screening, and Clinical Frailty Scale (CFS) [1, 14]. Among them, the CFS is the most widely applied assessment tool [15]. The CFS is a simple, rapid screening test proposed by Rockwood and colleagues [2]. The CFS was based on the theoretical model of fitness, frailty, and function; it was developed as a grading tool with seven scales in 2005 [2] and revised in 2008 to include a total of nine scales. The CFS is composed of visual and written charts for frailty with nine graded pictures [2] and it takes less than 5 min to complete [14]. The CFS was developed to measure the frailty based on clinical judgement $[2,14]$, and studies have shown that CFS is useful to predict clinical outcomes in various clinical settings such as emergency department, intensive care units or postoperative [5, 16-19]. Because of its usefulness, the original English version of the CFS has been translated in different languages [12, 20, 21].

In Korea, The Eastern Cooperative Oncology Group Performance Status (ECOG PS) scale, the Korean version of FRAIL (K-FRAIL), Korean Cancer Study Group Geriatric Score (KG-7), and Korean Frailty Index are commonly used to assess frailty due to lack of appropriate measures [22-25]. However, these tools require more time for completion than the CFS, and most are limited to cancer patients. Herein, we aimed to validate the Korean version of the CSF (CSF-K). Specifically, we translated the CSF into Korean and evaluated its contents validity. In addition, we also evaluate specificity and sensitivity of the CSF-K and concurrent validity by comparing with other scales.

\section{Methods \\ Participants}

We prospectively enrolled 100 patients aged $\geq 65$ years who visited an outpatient clinic or were admitted to the general ward or intensive care units of the Samsung Medical Center and Samsung Changwon Hospital between August 2019 and April 2020. The patients were eligible to participate if they or their guardians, who were closely involved in their care, gave informed consent to measure frailty. Patients diagnosed with dementia were excluded. The Institutional Review Board of the Samsung Medical Center (IRB No. 2019-02-028-004) and Samsung Changwon Hospital (IRB No. 2019-06-003) approved this study, and each participant provided informed written consent.

\section{Translation of clinical frailty scale to Korean}

Original CFS in English consists of a scale from 1 (very fit) to 9 (terminally ill), which is scored by clinical judgment; hence, the last group is technically not frail [2] (Fig. 1). To develop the CFS-K, we obtained copyright permission from Dr. Rockwood, who developed the original CFS. Three bilingual experts translated the CFS to Korean independently; then, it was back translated to English by three independent bilingual experts [26]. After this process, a multidisciplinary team of experts, including intensivists, intensive care unit nurses, an expert in geriatric medicine, behavioral scientists, and clinicians, reviewed and confirmed the instruments' content (Fig. 1). In addition, a pilot test with five patients confirmed the content validity of the scale (data not shown).

\section{Measurements}

To assess the baseline cognitive function, we used the Korean version of the Mini-Mental State Examination (K-MMSE) [27]. Other demographic and clinical 


\begin{tabular}{|c|c|c|}
\hline Category & Clinical frailty scale & Clinical frailty scale-Korean \\
\hline 1 & $\begin{array}{l}\text { Very Fit - People who are robust, active, energetic and motivated. These people } \\
\text { commonly exercise regularly. They are among the fittest for their age. }\end{array}$ & $\begin{array}{l}\text { 매우 건강함 - 원기 왕성하고, 활동적이며, 활기차고, 의욕적입니다. 여기 } \\
\text { 에 속하는 사람들은 규칙적으로 운동을 합니다. 또래 중에는 가장 건강 } \\
\text { 한 편에 속합니다. }\end{array}$ \\
\hline 2 & $\begin{array}{l}\text { Well - People who have no active disease symptoms but are less fit than category } \\
\text { 1. Often, they exercise or are very active occasionally, e.g. seasonally. }\end{array}$ & $\begin{array}{l}\text { 건강함 - 현재 질병으로 인한 증상이 없는 사람들이지만 } 1 \text { 번 범주의 사 } \\
\text { 람들보다는 덜 건강합니다. 이들은 가끔 운동을 하거나 활동적인 일을 } \\
\text { 할 수 있습니디다. (예를 들어, 계절적으로) }\end{array}$ \\
\hline 3 & $\begin{array}{l}\text { Managing Well - People whose medical problems are well controlled, but are not } \\
\text { regularly active beyond routine walking. }\end{array}$ & $\begin{array}{l}\text { 잘 관리됨 - 의학적인 문제들은 있으나 잘 조절이 되고 있는 상태입니 } \\
\text { 다. 일상적인 걷기 이상의 규칙적인 활동은 하지 않는 사람들입니다. }\end{array}$ \\
\hline 4 & $\begin{array}{l}\text { Vulnerable - While not dependent on others for daily help, often symptoms limit } \\
\text { activities. A common complaint is being "slowed up", and/or being tired during the } \\
\text { day. }\end{array}$ & $\begin{array}{l}\text { 취약함 - 일상생활에 다른 사람의 도움이 필요하지는 않지만 질병에 의 } \\
\text { 한 증상으로 인해 종종 활동에 제한을 받습니다. 흔히 움직임이 느려지 } \\
\text { 거나 낮에 피곤함을 느낍니다. }\end{array}$ \\
\hline 5 & $\begin{array}{l}\text { Mildly Frail - These people often have more evident slowing, and need help in } \\
\text { high order IADLs (finances, transportation, heavy housework, medications). } \\
\text { Typically, mild frailty progressively impairs shopping and walking outside alone, } \\
\text { meal preparation and house work. }\end{array}$ & $\begin{array}{l}\text { 경증 쇠약 - 여기 속한 사람들은 더욱 움직임이 느려지며, 높은 단계의 } \\
\text { 일상생활(돈 관리, 교통수단 이용, 힘든 집안일, 약 복용) 등에 도움이 } \\
\text { 필요합니다. 보통 경증 쇠약은 혼자 장보고 외출하기, 식사 준비와 집안 } \\
\text { 일 하는 것을 점차 어렵게 합니다. }\end{array}$ \\
\hline 6 & $\begin{array}{l}\text { Moderately Frail - People need help with all outside activities and with keeping } \\
\text { house. Inside, they often have problems with stairs and need help with bathing and } \\
\text { might need minimal assistance (cuing, standby) with dressing. }\end{array}$ & $\begin{array}{l}\text { 중등도 쇠약 - 모든 바깥 활동과 집안일을 하는데 도움이 필요합니다. } \\
\text { 실내에서는 일반적으로 계단을 오르거나 목욕을 하는데 어려움이 있고, } \\
\text { 씻고 옷을 갈아 입을 때 다른 사람의 도움이 필요합니다. }\end{array}$ \\
\hline 7 & $\begin{array}{l}\text { Severely Frail - Completely dependent for personal care, from whatever cause } \\
\text { (physical or cognitive). Even so, they seem stable and not at high risk of dying } \\
\text { (within } \sim 6 \text { months). }\end{array}$ & $\begin{array}{l}\text { 중증 쇠약 - 어떤 이유(신체 장애 혹은 인지 장애)로든 개인위생(목욕, } \\
\text { 양치, 세수)까지 완전히 남에게 의존적인 삶이 된 상태입니다. 그렇지만 } \\
\text { 안정적 이여서 곧(6개월 이내에) 사망할 위험성은 높지 않은 사람들입니 } \\
\text { 다. }\end{array}$ \\
\hline 8 & $\begin{array}{l}\text { Very Severely Frail - Completely dependent, approaching the end of life. } \\
\text { Typically, they could not recover even from a minor illness. }\end{array}$ & $\begin{array}{l}\text { 고도 중증 쇠약 - 완전히 의존적이며 임종기로 진행 중인 상태입니다. } \\
\text { 보통, 이들은 경미한 질병이라도 회복하기 어렵습니다. }\end{array}$ \\
\hline 9 & $\begin{array}{l}\text { Terminally III - Approaching the end of life. This category applies to people with } \\
\text { a life expectancy }<6 \text { months, who are not otherwise evidently frail. }\end{array}$ & $\begin{array}{l}\text { 말기 - 임종기로 진행하는 사람들입니다. 눈에 띄게 쇠약하지 않지만 기 } \\
\text { 대 여명이 } 6 \text { 개월 미만인 사람들이 이 범주에 해당합니다. }\end{array}$ \\
\hline
\end{tabular}

Fig. 1 Original and Korean versions of Clinical Frailty Scale

information including comorbidity, admitted location, and primary reason for admission were obtained from the participants' medical records.

To examine the concurrent validity, we used the ECOG PS, K-FRAIL scale, KG-7, and Korean Frailty Index $[22-25,28]$. The ECOG PS scale is a measurement tool used to describe a patient's level of functioning from 0 to 5 , with increasing scores indicating increasing levels of deterioration [22]. The K-FRAIL scale is a screening tool for measuring frailty status using a five-item questionnaire, which ranged 1 to 5 , with increasing scores indicating increasing frailty [23]. The KG-7 is a screening tool for geriatric assessment using seven items representing each domain of the geriatric assessment scale, which ranged 0 to 7 [24], with decreasing scores indicating increasing deterioration. The Korean Frailty Index is an eight-item questionnaire that measures frailty in older patients, with scores ranging from 0 to 8 , and high scores indicating increasing levels of deterioration [25].

\section{Statistical methods}

Data analyses included descriptive statistics (frequencies, means, and standard deviations) and statistical analyses for assessing frailty. In order to measure the CFS-K's concurrent validity, Pearson's coefficients for correlation between CFS and the other scales including the KG-7,
K-FRAIL, and Korean Frailty Index, and Spearman's rank-order for correlation between CFS and ECOG PS were computed. In addition, we calculated the sensitivity and specificity of identifying ECOG 3 or more using the area under the curve (AUC). The performance for identifying frailty was compared between CFS-K and the K-FRAIL, KG-7, and Korean Frailty Index, with Bonferroni's correction to adjust for multiple comparisons. For the analyses, KG-7 was recorded in reverse to achieve the same direction scores. We used the two way sided $p$-values to compare the AUC of CFS$\mathrm{K}$ with AUC of other frailty screening tests. The significance level was set at 0.05 . All analyses were performed using STATA version 15 (Stata Corp LP, College Station, TX, USA).

\section{Results}

\section{Participant characteristics}

The participants' characteristics are demonstrated in Table 1. A total 100 outpatient $(n=10,10.0 \%)$ and inpatient $(n=90,90.0 \%)$ participants were recruited at two medical centers. The mean age of the study participants was 75.6 years old and $63.0 \%$ were men. The mean body mass index was $21.7 \mathrm{~kg} / \mathrm{m}^{2}$ (standard deviation $[\mathrm{SD}], 3.5 \mathrm{~kg} / \mathrm{m}^{2}$ ). Among the participants, the common comorbidity was chronic lung disease including chronic obstructive pulmonary disease, asthma, and interstitial 
Table 1 Characteristics of the study participants

\begin{tabular}{|c|c|}
\hline & Participants $(N=100)$ \\
\hline Age (years) & $75.6(7.0)$ \\
\hline \multicolumn{2}{|l|}{ Sex } \\
\hline Male & $63(63.0)$ \\
\hline Female & $37(37.0)$ \\
\hline Body mass index $\left(\mathrm{kg} / \mathrm{m}^{2}\right)$ & $21.7(3.5)$ \\
\hline \multicolumn{2}{|l|}{ Comorbidity } \\
\hline Chronic lung disease & $44(44.0)$ \\
\hline Hypertension & $38(38.0)$ \\
\hline Cancer (oncology/hematology) & $32(32.0)$ \\
\hline Diabetes & $30(30.0)$ \\
\hline Cardiac disease (ischemic/vascular) & $26(26.0)$ \\
\hline Cerebrovascular disease & $17(17.0)$ \\
\hline Chronic kidney disease & $11(11.0)$ \\
\hline \multicolumn{2}{|l|}{ Location } \\
\hline Outpatient & $10(10.0)$ \\
\hline Inpatient & $90(90.0)$ \\
\hline \multicolumn{2}{|c|}{ Primary admission cause in ward patients $(N=90)$} \\
\hline Pneumonia & $38(42.2)$ \\
\hline AE of underlying lung disease & $11(12.2)$ \\
\hline Cardiac disease & $14(15.6)$ \\
\hline Other infection & $5(5.6)$ \\
\hline Cancer related problems & $22(24.4)$ \\
\hline K-MMSE score ${ }^{a}$ & $22.2(7.2)$ \\
\hline
\end{tabular}

K-MMSE Korean version of the Mini-Mental State Examination Values are mean (SD) or number (\%)

${ }^{a}$ Data were obtained from 96 (96\%) participants lung disease (44\%), followed by hypertension (38\%) and cancer $(32 \%)$. For the 90 inpatients, the primary reason for admission was pneumonia (42.2\%) followed by cancer-related management (24.4\%). Of the 10 outpatients, 9 visited for pulmonary disease (90\%), and one visited for cardiovascular disease (10\%). K-MMSE was measured in 96 (96\%) patients and the mean score of the K-MMSE was 22.2 (SD 7.2).

\section{Characteristics by clinical frailty scale-Korean}

All of the participants completed the CFS-K, and the mean score was 4.8 (SD, 2.5). The characteristics of the participants are grouped by CFS-K scale (Table 2). Except for patients assigned to scale 9 (terminally ill), the mean age and proportion of males were different for each scale but without significance ( $\mathrm{P}$ for trends 0.576 and 0.052 , respectively). Body mass index was higher in patients assigned to scales 1 (very fit)-4 (vulnerable) than in those assigned to scales 5 (mildly frail)-8 (very severely frail), at a significant level ( $\mathrm{P}$ for trend 0.013). The K-MMSE data were obtained from 96 (96\%) of all the participants. The patients assigned to scale 1 (very fit) had the highest (mean (standard deviation [SD])) K-MMSE score (28.7 (2.7)) and those assigned to scale 8 (very severely frail) had the lowest KMMSE score (12.7(8.1)) with significant difference across the groups ( $P$ for trends $<0.001$ ). The body mass index of patients assigned to scale 9 (terminally ill) was higher than that of patients assigned to scale 2 (well) and the K-MMSE score $(21.0$ (8.7)) of patients assigned to scale 6 (moderately frail) (18.9 (5.9)) was higher than that of patients assigned to other scales.

Table 2 Characteristics of the study participants as per Clinical Frailty Scale-Korean

\begin{tabular}{|c|c|c|c|c|c|c|c|c|c|}
\hline & $\begin{array}{l}1 \text { Very } \\
\text { fit }\end{array}$ & 2 Well & $\begin{array}{l}3 \text { Managing } \\
\text { well }\end{array}$ & $\begin{array}{l}4 \\
\text { Vulnerable }\end{array}$ & $\begin{array}{l}5 \text { Mildly } \\
\text { frail }\end{array}$ & $\begin{array}{l}6 \text { Moderately } \\
\text { frail }\end{array}$ & $\begin{array}{l}7 \text { Severely } \\
\text { frail }\end{array}$ & $\begin{array}{l}8 \text { Very severely } \\
\text { frail }\end{array}$ & $\begin{array}{l}9 \\
\text { Terminally } \\
\text { ill }\end{array}$ \\
\hline No. of patients & 10 & 12 & 11 & 16 & 12 & 10 & 10 & 11 & 8 \\
\hline Age, years & $73.2(6.6)$ & $78.7(8.3)$ & 74.3 (3.6) & $72.8(6.9)$ & $76.7(7.0)$ & $77.8(7.9)$ & 76.9 (8.0) & $75.5(7.7)$ & $75.8(4.6)$ \\
\hline Male, $n$ & $7(70.0)$ & $9(75.0)$ & $5(45.5)$ & $13(81.2)$ & $9(75.0)$ & $5(50.0)$ & $3(30.0)$ & $5(45.5)$ & $7(87.5)$ \\
\hline $\begin{array}{l}\text { Body mass index }(\mathrm{kg} / \\
\left.\mathrm{m}^{2}\right)\end{array}$ & $23.5(1.1)$ & $21.6(4.2)$ & $22.8(2.7)$ & $22.4(2.9)$ & $20.3(3.3)$ & $21.2(3.9)$ & $21.0(5.3)$ & $19.8(2.3)$ & $23.0(3.0)$ \\
\hline \multicolumn{10}{|l|}{ K-MMSE } \\
\hline Mean (SD) & $28.2(2.7)$ & $23.5(7.9)$ & $24.5(4.0)$ & $25.8(3.5)$ & $24.4(3.6)$ & $18.9(5.9)$ & $18.3(7.3)$ & $12.7(8.1)$ & $21(8.7)$ \\
\hline Median (IQR) & $\begin{array}{l}29(27- \\
30)\end{array}$ & $\begin{array}{l}25(23.5- \\
27.5)\end{array}$ & $26(22-28)$ & $\begin{array}{l}27(25.5- \\
28)\end{array}$ & $\begin{array}{l}25.5(22- \\
27)\end{array}$ & $17(16-25)$ & $\begin{array}{l}15.5(13- \\
26)\end{array}$ & $13(7-20)$ & $\begin{array}{l}24(21.5- \\
25)\end{array}$ \\
\hline
\end{tabular}

K-MMSE Korean version of the Mini-Mental State Examination

Values in the Table are mean (SD), median (IQR), or number (\%)

$P$ for trends for body mass index $(p=0.013)$ and K-MMSE $(p<0.001)$ were statistically significant. $p$ for trends for age $(p=0.576)$ and sex $(p=0.052)$ were not significant. We excluded participants who were assigned to scale 9 (terminally ill) on the Clinical Frailty Scale-Korean 
Correlation between frailty measures and clinical frailty scale-Korean and validation

The frailty scores by CFS-K are summarized in Table 3 . The patients assigned to scale 1 (very fit) had the highest KG7 score $(6.7(0.7))$ and the lowest scores on the KFRAIL $(0.3(0.5))$ and Korean Frailty Index (1.2 (1.3)). All of the patients with CFS-K 1 (very fit) showed ECOG PS grade $0(80 \%)$ or $1(20 \%)$. In contrast, the patients assigned to scale 8 (very severely frail) had the lowest KG7 score $(0.8(1.0))$ and the highest score of K-FRAIL (3.7 (0.5)) and Korean Frailty Index (6.8 (1.1)). Patients with CFS-K 8 showed ECOG PS grade $3(30 \%)$ or 4 (70\%). Regarding patients assigned to scale 9 (terminally ill), the mean (SD) of KG7 (3.9 (2.0)), K-FRAIL (2.9 (1.2)), and Korean frailty index (4.9 (1.5)) were similar to those assigned to scale 4 (vulnerable) or 5 (mildly frail). The ECOG PS scores were inconsistent among patients assigned to scale 9 (terminally ill). The CFS-K scores were positively correlated with K-FRAIL $(\mathrm{R}=0.8053)$ and Korean Frailty Index $(R=0.7742)$, ECOG PS $(R=0.9190)$ scores and negatively correlated with KG-7 $(\mathrm{R}=-0.8846)$ scores, except in the case of patients assigned to scale 9 on the CSF-K (terminally ill).

Regarding the receiver operating characteristic (ROC) curve for identifying ECOG PS grade 3 or more, the CFS-K showed better performance $(\mathrm{AUC}=0.99)$ than the KG-7 (AUC $=0.96 ; p=0.08$ ), K-FRAIL $(\mathrm{AUC}=0.89$; $p<0.01$ ), and Korean Frailty Index (AUC 0.87; $p<0.01$ ) (Fig. 2). In addition, the CFS-K has a sensitivity of $90.6 \%$ and a specificity of $97.0 \%$ for identifying ECOG PS grade 3 or more.

\section{Discussion}

In this study, we translated the CFS into Korean and evaluated the content and concurrent validity by comparing it with other scales, namely the ECOG PS, KFRAIL, KG-7, and Korean Frailty Index. The patients were subjected all of the scales regardless of age or sex. High scores on the CFS-K were correlated to low body mass index and low K-MMSE score. The CFS-K scores

Table 3 Performance of K-CFS against that of K-FRAIL, KG-7, Korean frailty index, and ECOG and Pearson's correlations between KCFS and other scales

\begin{tabular}{|c|c|c|c|c|c|c|c|c|c|c|c|}
\hline & $\begin{array}{l}1 \\
\text { Very } \\
\text { fit }\end{array}$ & 2 Well & $\begin{array}{l}3 \\
\text { Managing } \\
\text { well }\end{array}$ & $\begin{array}{l}4 \\
\text { Vulnerable }\end{array}$ & $\begin{array}{l}5 \text { Mildly } \\
\text { frail }\end{array}$ & $\begin{array}{l}6 \\
\text { Moderately } \\
\text { frail }\end{array}$ & $\begin{array}{l}7 \text { Severely } \\
\text { frail }\end{array}$ & $\begin{array}{l}8 \text { Very } \\
\text { severely frail }\end{array}$ & $\begin{array}{l}9 \\
\text { Terminally } \\
\text { ill }\end{array}$ & $\mathrm{R}^{\mathrm{a}}$ & $\mathbf{R}_{\mathrm{s}}^{\mathrm{a}}$ \\
\hline$\overline{\text { K-FRAIL }}$ & & & & & & & & & & $0.8053^{*}$ & $0.8048^{*}$ \\
\hline Mean (SD) & $\begin{array}{l}0.3 \\
(0.5)\end{array}$ & $\begin{array}{l}0.7 \\
(0.8)\end{array}$ & $0.8(1.3)$ & $1.3(0.9)$ & $3.3(0.9)$ & $3.8(0.4)$ & $3.5(1.0)$ & $3.7(0.5)$ & $2.9(1.2)$ & & \\
\hline Median (IQR) & $\begin{array}{l}0(0- \\
1)\end{array}$ & $\begin{array}{l}0.5(0- \\
1)\end{array}$ & $0(0-1)$ & $1(1-2)$ & $3.5(3-4)$ & $4(4-4)$ & $4(3-4)$ & $4(3-4)$ & $3(2-3.5)$ & & \\
\hline KG-7 & & & & & & & & & & $-0.8846^{*}$ & $-0.8860^{*}$ \\
\hline Mean (SD) & $\begin{array}{l}6.7 \\
(0.7)\end{array}$ & $\begin{array}{l}5.4 \\
(1.2)\end{array}$ & $5.5(1.0)$ & $4.3(1.1)$ & $3.4(0.7)$ & $1.8(1.0)$ & $1.0(1.2)$ & $0.8(1.0)$ & $3.9(2.0)$ & & \\
\hline Median (IQR) & $\begin{array}{l}7(7- \\
7)\end{array}$ & $\begin{array}{l}5(5- \\
6.5)\end{array}$ & $6(5-6)$ & $4(3-5)$ & $3.5(3-4)$ & $1.5(1-2)$ & $1(0-1)$ & $1(0-1)$ & $3.5(2-5.5)$ & & \\
\hline $\begin{array}{l}\text { Korean frailty } \\
\text { index }\end{array}$ & & & & & & & & & & $0.7742^{*}$ & $0.7883^{*}$ \\
\hline Mean (SD) & $\begin{array}{l}1.2 \\
(1.3)\end{array}$ & $\begin{array}{l}3.3 \\
(1.4)\end{array}$ & $2.2(1.4)$ & $4.3(1.4)$ & $5.8(1.1)$ & $5.2(0.9)$ & $6.2(1.2)$ & $6.8(1.1)$ & $4.9(1.5)$ & & \\
\hline Median (IQR) & $\begin{array}{l}1(0- \\
2)\end{array}$ & $3(2-5)$ & $3(1-3)$ & $4(3-5.5)$ & $6(5.5-6)$ & $5.5(4-6)$ & $6.5(5-7)$ & $7(6-8)$ & $5(3.5-6)$ & & \\
\hline ECOG PS & & & & & & & & & & $0.9190^{*}$ & $0.9184^{*}$ \\
\hline 0 & $\begin{array}{l}8 \\
(80.0)\end{array}$ & $3(25.0)$ & $2(18.2)$ & $1(6.3)$ & 0 & 0 & 0 & 0 & $1(12.5)$ & & \\
\hline 1 & $\begin{array}{l}2 \\
(20.0)\end{array}$ & $9(75.0)$ & $9(81.8)$ & $13(81.3)$ & $1(8.3)$ & $1(8.3)$ & 0 & 0 & $2(25.0)$ & & \\
\hline 2 & 0 & 0 & 0 & $2(12.5)$ & $8(66.7)$ & $8(66.8)$ & $2(20.0)$ & 0 & $4(50.0)$ & & \\
\hline 3 & 0 & 0 & 0 & 0 & $3(25.0)$ & $8(80.0)$ & $8(80.0)$ & $3(30.0)$ & $1(12.5)$ & & \\
\hline 4 & 0 & 0 & 0 & 0 & 0 & 0 & 0 & $7(70.0)$ & 0 & & \\
\hline
\end{tabular}

K-CFS Clinical Frailty Scale-Korean, K-FRAIL Korean version of the fatigue, resistance, ambulation, illness, and loss of weight, KG-7 Korean Cancer Study Group Geriatric Score, ECOG PS Eastern Cooperative Oncology Group Performance Status

$\mathrm{R}$ and $\mathrm{R}_{\mathrm{s}}$ were calculated using Pearson correlation and Spearman correlation, respectively

$P$ for trends for all the variables were statistically significant $(p<0.001)$

We excluded participants who were assigned to scale 9 (terminally ill) on the Clinical Frailty Scale-Korean * $p<0.01$ 


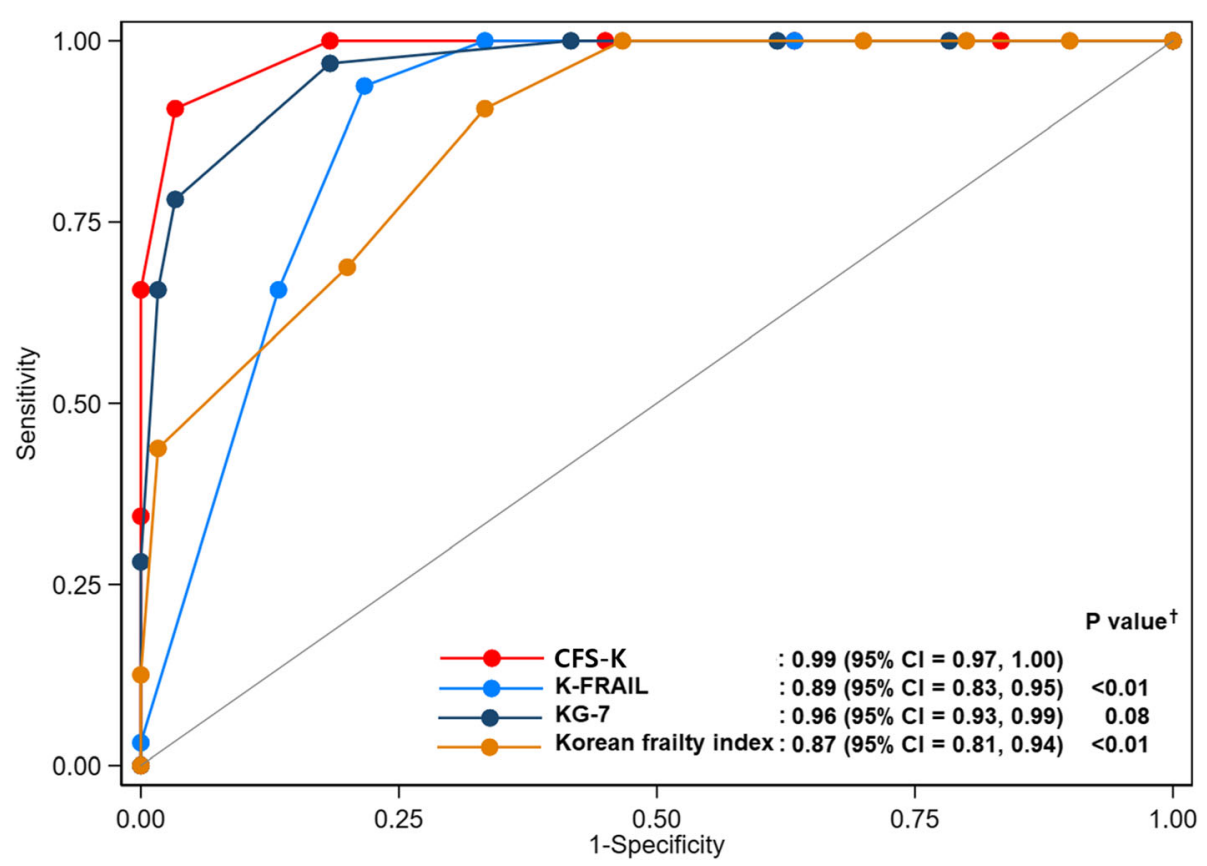

Fig. 2 Receiver operating characteristic (ROC) curves of frailty measures for identifying ECOG PS 3 or more ( $N=92)$. In this figure, KG-7 was recorded as reverse to achieve the same direction scores. The participants assigned to CFS-K scale 9 (terminally ill) were excluded in this analysis. ${ }^{\dagger} P$ values were obtained to compare the ROC curves, and Bonferroni's correction was used to adjust for multiple comparisons

were significantly correlated with the scores of other scales and showed the best assessment of frailty.

The CFS-K was found to be a useful screening tool of frailty in Korean older patients. In this study, the newly translated Korean version of CFS recognized frail patients more effectively than other scales. Previous studies have suggested the CFS is a useful screening tool based on clinical judgement for measuring frailty $[8,14]$. the translated version was also administered successfully. Moreover, the CFS-K correlated well with other scales including the ECOG PS, K-FRAIL, KG-7, and Korean Frailty Index, which are already used in clinical settings. Previous study showed that CFS has a sensitivity of $56.0 \%$ and a specificity $98.4 \%$ for identifying frail according to the definition of $\mathrm{CHS}$ frailty screening. In this study, the CFS-K also investigated concurrent validity. With the AUC of 0.99 , a sensitivity $90.6 \%$, and a specificity of $97.0 \%$, the CFS-K showed excellent performance for identifying ECOG PS grade 3 or more. As the CFS has predictive and prognostic features with regard to clinical outcomes in various clinical settings $[5,16,17]$, the CFS-K could be a useful screening tool for frail older in South Korea and also help provide optimal management.

Interestingly, the body mass index and K-MMSE score showed significant differences across the CSF-K scales. The relationship between frailty and sarcopenia has been reported in several studies [29, 30]; this study showed consistent results. Since low body mass index is an important risk factor of poor prognosis [31, 32], high scores on the CFS-K would be associated with poor clinical outcomes. The association between frailty and cognitive decline has been reported, and the results were consistent with previous findings $[33,34]$. As important clinical characteristics can be distinguished by quick assessment with the CFS-K, it can be a valuable tool for frailty screening.

The patients assigned to scale 9 (terminally ill) showed unique characteristics. Because of the definition, for patients who were not evidently frail but had less than 6 months' life expectancy, the scores of frailty indexes were between scale 4 (vulnerable) and scale 5 (mildly frail) and the ECOG PS score also ranged from 0 to 3; their body mass index and K-MMSE scores were also relatively high. In this study, the patients diagnosed with advanced solid or hematologic malignancy with high tumor burden were assigned to scale 9 (terminally ill). Nowadays, the life expectancy is increasing due to improvement in cancer treatment, organ transplantation, and critical care with organ-supporting systems [35-39]. Further studies regarding scale 9 (terminally ill) patients' clinical outcomes and prognosis are warranted.

This study has some limitations. First, the validation of the CFS-K was performed with a relatively small number of participants. Second, this study included outpatients and inpatients, not a community-based population. Moreover, only patients who gave consent were enrolled. These factors might have caused selection bias. Further 
large-scale studies with general population and patients in various clinical settings are warranted.

\section{Conclusions}

In conclusion, the CFS-K is a valid scale for measuring frailty in older Korean patients. The CFS-K scores were significantly correlated with the scores of other scales. To evaluate the predictive and prognostic value of this scale, further larger-scale studies in various clinical settings are warranted.

\begin{abstract}
Abbreviations
FRAlL: Fatigue, Resistance, Ambulation, Illness, and Loss of weight; CHS: Cardiovascular Health Study; CFS: Clinical Frailty Scale; ECOG PS: Eastern Cooperative Oncology Group Performance Status; K-FRAIL: Korean version of the fatigue, resistance, ambulation, illness, and loss of weight; KG-7: Korean Cancer Study Group Geriatric Score; CFS-K: Korean version of Clinical Frailty Scale; K-MMSE: Korean version of the Mini-Mental State Examination; AUC: Area under the curve; SD: Standard deviation; ROC: Receiver operating characteristic

\section{Acknowledgments}

Not applicable.

\section{Authors' contributions}

R.E.K.: Conceptualization, data curation, resources, formal analysis, writing of original draft, and methodology. S.M.M.: Conceptualization, data curation, collection of resources, formal analysis, writing of original draft, and methodology. S.H.L.: Data curation and reviewing/editing. J.H.L.: Data curation and reviewing/editing. D.K.: Conceptualization, data curation, formal analysis, writing of original draft, and methodology. J.C.: Conceptualization, data curation, formal analysis, writing of original draft, and methodology. C.R.C.: Conceptualization and review/editing. Y.L.: Conceptualization and review/editing. Y.S.H.: Conceptualization, methodology, and reviewing/ editing. G.Y.S.: Conceptualization, collecting of resources, data curation, formal analysis, writing of original draft, review/editing, methodology, and
\end{abstract} supervision. All authors read and approved the final manuscript.

\section{Funding}

This research was supported by a grant of the Korea Health Technology R\&D project through the Korea Health Industry Development Institute (KHIDI), funded by the Ministry of Health \& Welfare, Republic of Korea (grant number: HI19C0481, HC19C0226). The funder had no role in the design of the study, the data collection and analysis, the interpretation of data and in writing the manuscript.

\section{Availability of data and materials}

The data that support the findings of this study are available on request from the corresponding author. The data are not publicly available due to privacy or ethical restrictions.

\section{Ethics approval and consent to participate}

The Institutional Review Board of the Samsung Medical Center (IRB No.201902-028-004) and Samsung Changwon Hospital (IRB No. 2019-06-003) approved this study, and each participant provided informed written consent.

\section{Consent for publication}

Not applicable.

\section{Competing interests}

The authors declare that they have no competing interests.

\section{Author details}

${ }^{1}$ Department of Critical Care Medicine, Samsung Medical Center, Sungkyunkwan University School of Medicine, 81 Irwon-ro, Gangnam-gu, Seoul 06351, Republic of Korea. ${ }^{2}$ Division of Pulmonary and Critical Care Medicine, Department of Medicine, Samsung Changwon Hospital,
Sungkyunkwan University School of Medicine, Changwon, Republic of Korea. ${ }^{3}$ Center for Clinical Epidemiology, Samsung Medical Center, Seoul, Republic of Korea. ${ }^{4}$ Department of Clinical Research Design and Evaluation, SAIHST, Sungkyunkwan University, Seoul, Republic of Korea. ${ }^{5}$ Department of Epidemiology, Johns Hopkins University Bloomberg School of Public Heath, Baltimore, MD, USA. ${ }^{6}$ Department of Preventive Medicine \& Public Health, Ajou University School of Medicine, Suwon, Republic of Korea. ${ }^{7}$ Institute on Aging, Ajou University Medical Center, Suwon, Republic of Korea.

${ }^{8}$ Departments of Epidemiology and Medicine, and Welch Center for Prevention, Epidemiology, and Clinical Research, Johns Hopkins University Bloomberg School of Public Health, Baltimore, MD, USA. ${ }^{9}$ Outpatient Nursing Team, Samsung Medical Center, Seoul, Republic of Korea. ${ }^{10}$ Medical Intensive Care Unit, Samsung Medical Center, Seoul, Republic of Korea. ${ }^{11}$ Division of Pulmonary and Critical Care Medicine, Department of Medicine, Samsung Medical Center, Sungkyunkwan University School of Medicine, Seoul, Republic of Korea.

Received: 6 September 2020 Accepted: 4 January 2021

Published online: 13 January 2021

\section{References}

1. Morley JE, Vellas B, van Kan GA, Anker SD, Bauer JM, Bernabei R, et al. Frailty consensus: a call to action. J Am Med Dir Assoc. 2013;14:392-7.

2. Rockwood K, Song X, MacKnight C, Bergman H, Hogan DB, McDowell I, et al. A global clinical measure of fitness and frailty in elderly people. CMAJ. 2005;173:489-95.

3. Kane RL, Shamliyan T, Talley K, Pacala J. The association between geriatric syndromes and survival. J Am Geriatr Soc. 2012;60:896-904.

4. Gilardi F, Scarcella P, Proietti MG, Capobianco G, Rocco G, Capanna A, et al. Frailty as a predictor of mortality and hospital services use in older adults: a cluster analysis in a cohort study. Eur J Pub Health. 2018;28:842-6.

5. Kaeppeli T, Rueegg M, Dreher-Hummel T, Brabrand M, Kabell-Nissen S, Carpenter $C R$, et al. Validation of the clinical frailty scale for prediction of thirty-day mortality in the emergency department. Ann Emerg Med. 2020; 76:291-300.

6. Yoshioka N, Takagi K, Morita Y, Yoshida R, Nagai H, Kanzaki Y, et al. Impact of the clinical frailty scale on mid-term mortality in patients with STelevated myocardial infarction. Int J Cardiol Heart Vasc. 2019;22:192-8.

7. Garcia-Canton C, Rodenas A, Lopez-Aperador C, Rivero Y, Anton G, Monzon $T$, et al. Frailty in hemodialysis and prediction of poor short-term outcome: mortality, hospitalization and visits to hospital emergency services. Ren Fail. 2019:41:567-75.

8. Darvall JN, Loth J, Bose T, Braat S, De Silva A, Story DA, et al. Accuracy of the clinical frailty scale for perioperative frailty screening: a prospective observational study. Can J Anaesth. 2020;67:694-705.

9. Chan S, Wong EKC, Ward SE, Kuan D, Wong CL. The predictive value of the clinical frailty scale on discharge destination and complications in older hip fracture patients. J Orthop Trauma. 2019:33:497-502.

10. Muscedere J, Waters B, Varambally A, Bagshaw SM, Boyd JG, Maslove D, et al. The impact of frailty on intensive care unit outcomes: a systematic review and meta-analysis. Intensive Care Med. 2017;43:1105-22.

11. Basic D, Shanley C. Frailty in an older inpatient population: using the clinical frailty scale to predict patient outcomes. J Aging Health. 2015;27:670-85.

12. Geense $W$, Zegers $M$, Dieperink $P$, Vermeulen $H$, van der Hoeven J, van den Boogaard M. Changes in frailty among ICU survivors and associated factors: results of a one-year prospective cohort study using the Dutch clinical frailty scale. J Crit Care. 2020;55:184-93.

13. Pilotto A, Cella A, Pilotto A, Daragjati J, Veronese N, Musacchio C, et al. Three decades of comprehensive geriatric assessment: evidence coming from different healthcare settings and specific clinical conditions. J Am Med Dir Assoc. 2017;18:192.e1-e11.

14. Dent E, Kowal P, Hoogendijk EO. Frailty measurement in research and clinical practice: a review. Eur J Intern Med. 2016;31:3-10.

15. Pugh RJ, Ellison A, Pye K, Subbe CP, Thorpe CM, Lone NI, et al. Feasibility and reliability of frailty assessment in the critically ill: a systematic review. Crit Care. 2018;22:49.

16. Gregorevic KJ, Hubbard RE, Lim WK, Katz B. The clinical frailty scale predicts functional decline and mortality when used by junior medical staff: a prospective cohort study. BMC Geriatr. 2016:16:117. 
17. Reichart D, Rosato S, Nammas W, Onorati F, Dalén M, Castro L, et al. Clinical frailty scale and outcome after coronary artery bypass grafting. Eur J Cardiothorac Surg. 2018;54:1102-9.

18. Wallis SJ, Wall J, Biram RW, Romero-Ortuno R. Association of the clinical frailty scale with hospital outcomes. Qjm. 2015;108:943-9.

19. Juma S, Taabazuing MM, Montero-Odasso M. Clinical frailty scale in an acute medicine unit: a simple tool that predicts length of stay. Can Geriatr J. 2016; 19:34-9.

20. Abraham P, Courvoisier DS, Annweiler C, Lenoir C, Millien T, Dalmaz F, et al. Validation of the clinical frailty score (CFS) in French language. BMC Geriatr. 2019;19:322

21. Chan DC, Tsou HH, Chen CY, Chen CY. Validation of the Chinese-Canadian study of health and aging clinical frailty scale (CSHA-CFS) telephone version. Arch Gerontol Geriatr. 2010;50:e74-80.

22. Oken MM, Creech RH, Tormey DC, Horton J, Davis TE, McFadden ET, et al. Toxicity and response criteria of the eastern cooperative oncology group. Am J Clin Oncol. 1982;5:649-55.

23. Jung HW, Yoo HJ, Park SY, Kim SW, Choi JY, Yoon SJ, et al. The Korean version of the FRAIL scale: clinical feasibility and validity of assessing the frailty status of Korean elderly. Korean J Intern Med. 2016;31:594-600.

24. Kim JW, Kim SH, Kim YJ, Lee KW, Kim KI, Lee JS, et al. A novel geriatric screening tool in older patients with cancer: the Korean cancer study group geriatric score (KG)-7. PLoS One. 2015;10:e0138304.

25. Hwang HS, Kwon IS, Park BJ, Cho B, Yoon JL, Won CW. The validity and reliability of Korean frailty index. J Korean Geriatr Soc. 2010;14:191-202.

26. Lent L, Hahn E, Eremenco S, Webster K, Cella D. Using cross-cultural input to adapt the functional assessment of chronic illness therapy (FACIT) scales. Acta Oncol. 1999;38:695-702.

27. Kang Y, Na DL, Hahn S. Reliability and validity of the Korean version of the way-finding effectiveness scale for persons with dementia. J Korean Neurol Assoc. 1997;15:300-8

28. Han C, Jo SA, Jo I, Kim E, Park MH, Kang Y. An adaptation of the Korean mini-mental state examination (K-MMSE) in elderly Koreans: demographic influence and population-based norms (the AGE study). Arch Gerontol Geriatr. 2008:47:302-10.

29. Wilson D, Jackson T, Sapey E, Lord JM. Frailty and sarcopenia: the potential role of an aged immune system. Ageing Res Rev. 2017:36:1-10.

30. Cruz-Jentoft AJ, Baeyens JP, Bauer JM, Boirie Y, Cederholm T, Landi F, et al. Sarcopenia: European consensus on definition and diagnosis: report of the European working group on sarcopenia in older people. Age Ageing. 2010; 39:412-23.

31. Hagii J, Metoki N, Saito S, Fujita A, Shiroto H, Sasaki S, et al. Low body mass index is a poor prognosis factor in Cardioembolic stroke patients with NonValvular atrial fibrillation. J Stroke Cerebrovasc Dis. 2018;27:3155-62.

32. Naffouje SA, Tulla KA, Khalaf Z, Salti GI. The impact of BMI extremes on disease-free survival and overall survival following cytoreductive surgery and hyperthermic intraperitoneal chemotherapy. J Gastrointest Oncol. 2019;10: 194-202.

33. Miyamura K, Fhon JRS, Bueno AA, Fuentes-Neira WL, Silveira R, Rodrigues RAP. Frailty syndrome and cognitive impairment in older adults: systematic review of the literature. Rev Lat Am Enfermagem. 2019;27:e3202.

34. Robertson DA, Savva GM, Kenny RA. Frailty and cognitive impairment--a review of the evidence and causal mechanisms. Ageing Res Rev. 2013;12: 840-51.

35. Jung KW, Won YJ, Kong HJ, Lee ES. Community of population-based regional Cancer $R$. cancer statistics in Korea: incidence, mortality, survival, and prevalence in 2015. Cancer Res Treat. 2018:50:303-16.

36. Mascaux C, Tomasini P, Greillier L, Barlesi F. Personalised medicine for nonsmall cell lung cancer. Eur Respir Rev. 2017;26:1.

37. Rana A, Gruessner A, Agopian VG, Khalpey Z, Riaz IB, Kaplan B, et al. Sunvival benefit of solid-organ transplant in the United States. JAMA Surg. 2015;150:252-9.

38. Falk L, Hultman J, Broman LM. Extracorporeal membrane oxygenation for septic shock. Crit Care Med. 2019;47:1097-105.

39. Goligher EC, Tomlinson G, Hajage D, Wijeysundera DN, Fan E, Juni P, et al. Extracorporeal membrane oxygenation for severe acute respiratory distress syndrome and posterior probability of mortality benefit in a post hoc Bayesian analysis of a randomized clinical trial. JAMA. 2018;320:2251-9.

\section{Publisher's Note}

Springer Nature remains neutral with regard to jurisdictional claims in published maps and institutional affiliations.

\section{Ready to submit your research? Choose BMC and benefit from:}

- fast, convenient online submission

- thorough peer review by experienced researchers in your field

- rapid publication on acceptance

- support for research data, including large and complex data types

- gold Open Access which fosters wider collaboration and increased citations

- maximum visibility for your research: over $100 \mathrm{M}$ website views per year

At $\mathrm{BMC}$, research is always in progress.

Learn more biomedcentral.com/submissions 